\title{
Complete and detailed methodological design is a prerequisite to ensure the stability of meta-analysis
}

\author{
Xue Yang ${ }^{1,2}$, Dongjun $\mathrm{Li}^{1,2}$, Jianhua $\mathrm{Li}^{1,2}$, Yuan $\mathrm{Ai}^{1,2}$, Zhigui $\mathrm{Ma}^{1,2}$ \\ ${ }^{1}$ Department of Pediatrics, West China Second University Hospital, Sichuan University, Chengdu, China; ${ }^{2}$ Key Laboratory of Obstetric \& \\ Gynecologic and Pediatric Diseases and Birth Defects, Ministry of Education, Sichuan University, Chengdu, China \\ Correspondence to: Zhigui Ma, MD. No. 20, Section 3, Renmin South Road, Wuhou District, Chengdu, China. Email: wosenknowit@163.com.
}

Submitted Oct 21, 2021. Accepted for publication Nov 02, 2021.

doi: $10.21037 / \mathrm{apm}-21-3075$

View this article at: https://dx.doi.org/10.21037/apm-21-3075

We read with great interest the article entitled "Systematic review and meta-analysis: transplanted hematopoietic stem cells and killer cells on leukemia" by Zhang et al. The authors gathered currently available evidence and provided valuable information about the combined effects of hematopoietic stem cell transplantation and killer cells on leukemia. They concluded that hematopoietic stem cell transplantation combined with killer cells effectively reduced the incidence of graft-versus-host disease in patients after stem cell transplantation, with no significant effect on overall survival or recurrence (1). Nevertheless, we would like to underline some issues when interpreting these findings.

First, the registration information of the study should be explained and highlighted in detail in the method section of the article. Registering an systematic review protocol is important because it promotes transparency and avoids potential biases, including selection and selective outcome reporting biases (2). Second, the search strategy of this study is not well established; the authors did not use MeSH terms in PubMed search. When we use MeSH terms, PubMed searches pertinent articles. Third, the authors chosed an inappropriate evaluation model when assessing the quality of the included articles. The Cochrane Collaboration's tool should not be used to evaluate nonrandomized controlled trials (3). Thus, we recommend that the Downs and Black tools (modified version) be used to evaluate the methodological quality of non-randomized cohort studies (4). In addition, Kappa scores measuring consistency between reviewers should also be provided in the paper. Finally, although the authors intended to compare the differences between combination therapy and monotherapy, subgroup analysis should be performed based on the type of treatment in the control group, since the pooling outcomes of leukemia-free survival rate showed a high degree of heterogeneity.

We respectfully appreciate Zhang et al. for providing us with an important meta-analysis that may guide clinical decision making. However, more large-sample, scientifically well-designed studies should be further conducted to clarify this issue.

\section{Acknowledgments}

Funding: This study was supported by Key R\&D Support Plan of Chengdu Science and Technology Bureau (2019-YF05-01140-SN), Key R\&D project of Science and Technology Department of Sichuan Province (2020YFS0253).

\section{Footnote}

Provenance and Peer Review: This article was a standard submission to the journal. The article did not undergo external peer review.

Conflicts of Interest: All authors have completed the ICMJE uniform disclosure form (available at https://dx.doi. org/10.21037/apm-21-3075). The authors have no conflicts of interest to declare.

Ethical Statement: The authors are accountable for all aspects of the work in ensuring that questions related to the accuracy or integrity of any part of the work are appropriately investigated and resolved. 
Open Access Statement: This is an Open Access article distributed in accordance with the Creative Commons Attribution-NonCommercial-NoDerivs 4.0 International License (CC BY-NC-ND 4.0), which permits the noncommercial replication and distribution of the article with the strict proviso that no changes or edits are made and the original work is properly cited (including links to both the formal publication through the relevant DOI and the license). See: https://creativecommons.org/licenses/by-nc-nd/4.0/.

\section{References}

1. Zhang Y, Song Y, Ni Q, et al. Systematic review and meta- analysis: transplanted hematopoietic stem cells and killer cells on leukemia. Ann Palliat Med 2021;10:7872-83.

2. Preferred reporting items for systematic review and metaanalysis protocols (PRISMA-P) 2015: elaboration and explanation. BMJ 2016;354:14086.

3. Higgins JP, Altman DG, Gøtzsche PC, et al. The Cochrane Collaboration's tool for assessing risk of bias in randomised trials. BMJ 2011;343:d5928.

4. Downs SH, Black N. The feasibility of creating a checklist for the assessment of the methodological quality both of randomised and non-randomised studies of health care interventions. J Epidemiol Community Health 1998;52:377-84.
Cite this article as: Yang X, Li D, Li J, Ai Y, Ma Z. Complete and detailed methodological design is a prerequisite to ensure the stability of meta-analysis. Ann Palliat Med 2021;10(12):1291512916. doi: 10.21037/apm-21-3075 